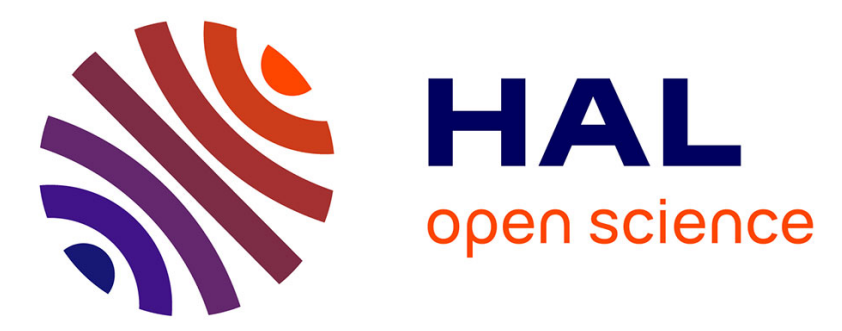

\title{
Improved leaf pruning reduces development of stem cankers caused by grey mould in greenhouse tomatoes
}

\author{
Véronique Decognet, F. Ravetti, C. Martin, Philippe C. Nicot
}

\section{To cite this version:}

Véronique Decognet, F. Ravetti, C. Martin, Philippe C. Nicot. Improved leaf pruning reduces development of stem cankers caused by grey mould in greenhouse tomatoes. Agronomy for Sustainable Development, 2010, 30 (2), pp.465-472. 10.1051/agro/2009030 . hal-00886532

\section{HAL Id: hal-00886532 https://hal.science/hal-00886532}

Submitted on 1 Jan 2010

HAL is a multi-disciplinary open access archive for the deposit and dissemination of scientific research documents, whether they are published or not. The documents may come from teaching and research institutions in France or abroad, or from public or private research centers.
L'archive ouverte pluridisciplinaire HAL, est destinée au dépôt et à la diffusion de documents scientifiques de niveau recherche, publiés ou non, émanant des établissements d'enseignement et de recherche français ou étrangers, des laboratoires publics ou privés. 


\title{
Improved leaf pruning reduces development of stem cankers caused by grey mould in greenhouse tomatoes
}

\author{
V. DECOGNET ${ }^{1}$, F. RAVETTI $^{2}$, C. MARTIN $^{3}$, P.C. NiCOT $^{1 *}$ \\ ${ }^{1}$ INRA, UR0407, Plant Pathology Unit, Domaine St Maurice, BP 94, 84143 Montfavet Cedex, France \\ ${ }^{2}$ L.E.P.A., 1016 avenue Jean Bouin, 84800 L'Isle-sur-la-Sorgue Cedex, France \\ ${ }^{3}$ PHYTEX, 1 rue Louis Torcatis, 66180 Villeneuve de la Raho Cedex, France
}

(Accepted 8 August 2009)

\begin{abstract}
Botrytis cinerea, the causal agent of grey mould, is considered as a major burden on greenhouse tomato production. In heated greenhouses, where leaf pruning is a routine practice and microclimatic conditions are favourable for grey mould development, infections of the pruning wounds result in stem cankers that can rapidly kill the plants. Chemical control is not always sufficiently effective and growers face increasing demands for reducing their dependency on pesticides. Several techniques can be used for the removal of leaves. They differ mainly on the presence or absence and the size of petiole stubs remaining on the stems after pruning. In this study, leaf pruning techniques were compared in an experimental greenhouse and the results validated in four commercial greenhouses, in a variety of agronomic conditions and in various situations of inoculum pressure. All experiments clearly showed that a careful removal of the leaves without leaving any petiole stubs on the stems can significantly decrease the incidence of stem cankers even under high disease pressure. As up to 10-fold differences were observed, this suggests the possibility of improving pruning practices in tomato greenhouses by removing leaves systematically close to the stem. This environmentally-friendly cultural practice appears compatible for integration with other preventative methods for the objective of sustainable crop protection in greenhouse tomatoes.
\end{abstract}

grey mould / Solanum lycopersicum / integrated pest management / sustainable crop protection

\section{INTRODUCTION}

Reduction of inputs for plant protection is an increasingly important issue in vegetable farming, both in terms of environmental impact and of consumer demand for pesticide-free food. Much research effort has been dedicated to the development of non-chemical pest control methods. Along with biological control methods, a variety of cultural practices have been gradually improved to suppress or limit the impact of pests and enhance the efficacy of integrated protection strategies, particularly for protected vegetable crops (Aissat et al., 2008; Candido et al., 2008; van Lenteren, 2000; Schellhorn et al., 2009; Shipp et al., 2007).

In heated tomato greenhouses, plants are typically trellised as single stems supported by binder twines that hang from an overhead wire. Leaves are periodically removed from the lower part of the stems, usually from the ripening of the first fruit cluster until the end of the season (Jarvis, 1992). Leaf removal facilitates the training of the plants and fruit harvest, and it hastens fruit maturation by increasing their exposure to light.

*Corresponding author: philippe.nicot@avignon.inra.fr
Removal of senescent older leaves also prevents their colonisation by weak pathogens which may subsequently spread to adjacent healthy tissues (Jarvis, 1980). Deleafing may also improve air circulation and render the microclimate less conducive to the development of humidity-dependent pathogens (Elad and Shtienberg, 1995). However, infection of pruning wounds by Botrytis cinerea, the causal agent of grey mould, is frequently observed in tomato greenhouses. The resulting stem cankers may girdle the stem over time, causing early death of the plants and significant yield reduction in long-season production systems (O'Neill et al., 1997). In a survey conducted in 15 greenhouses in southern France, the incidence of plants with stem infections ranged from 32 to $100 \%$ and plant mortality as high as $46 \%$ was observed (Nicot and Baille, 1996).

In the absence of resistant commercial tomato varieties (ten Have et al., 2007; see Williamson et al., 2007 for review), grey mould control is mainly based on the integration of chemical treatments with climate management and cultural methods (Elad and Shtienberg, 1995). However, prevention of wound infection with fungicide sprays is not always effective, as the chemicals may fail to cover adequately all the pruning wounds present on the plants. Chemical control 
Table I. Main characteristics of the five tomato greenhouses used in the study.

\begin{tabular}{|c|c|c|c|c|c|c|}
\hline Location & Surface $\left(\mathrm{m}^{2}\right)$ & Substrate & Cultivar & Plants $/ \mathrm{m}^{2}$ & \multicolumn{2}{|c|}{ Climatic data $^{a}$} \\
\hline INRA Montfavet & 100 & peat mix & Rondello & 2.2 & $24.7^{\circ} \mathrm{C}(18-30)$ & $86 \%(60-99)$ \\
\hline L'Isle/Sorgue 1 & 5800 & soil & Recento & 2.5 & $18.0^{\circ} \mathrm{C}(11-34)$ & $80 \%(40-98)$ \\
\hline L'Isle/Sorgue 2 & 3200 & soil & Recento & 2.5 & $18.2^{\circ} \mathrm{C}(11-34)$ & $82 \%(40-98)$ \\
\hline Perpignan & 1000 & soil & Prisca & 2.0 & $23.1^{\circ} \mathrm{C}(12-28)$ & $83 \%(55-98)$ \\
\hline Pertuis & 4200 & blond peat & Rondello & 2.3 & $20.4{ }^{\circ} \mathrm{C}(12-32)$ & $77 \%(40-90)$ \\
\hline
\end{tabular}

${ }^{a}$ Mean temperature and mean relative humidity during the period of leaf removal and disease monitoring (February to August, depending on the experiment). Numbers in brackets indicate the range.

in tomato greenhouses is further complicated by the occurrence of strains of $B$. cinerea resistant to fungicides and by the decreasing number of registered active substances (Leroux, 2004). The curative application of fungicides on individual stem cankers, to prevent or delay stem girdling, is a common, labour-intensive practice of tomato growers. This practice is not always sufficient as the treated cankers may resume their extension and become a source of fungicide-resistant inoculum (Besri and Diatta, 1992; Nicot and Baille, 1996).

In a context of sustainable production, there is a need for additional non-chemical preventative tools that can be integrated with other control methods. One example of such tools is the development of improved pruning practices which reduce the occurrence of wound infection. Growers are advised to prune the plants on sunny days and to irrigate early rather than late in the day, in order to promote the drying of leaf scars and thus decrease their susceptibility (Dik and Wubben, 2004; Jarvis, 1992). However, the routine adoption of such practices may be limited by technical and labour management constraints. At present, there is a lack of knowledge with respect to the optimum pruning technique. In commercial tomato production, a wide variety of pruning practices can be observed. Some growers break off the leaves by hand while others use various cutting implements such as knives, cutters or pruning shears. These tools may be dipped in a disinfecting solution and some are even fitted with a device, linked to a small reservoir, which delivers small amounts of disinfectant directly on the blade. Depending on the methods and tools that are used, stubs of varying length can be left on the stem after pruning. In an experiment on the pruning of flower trusses after fruit harvest, a correlation was reported between the occurrence of truss stubs on the plants and development of Botrytis stem cankers (O'Neill et al., 1998). In earlier studies on leaf pruning, the incidence of Botrytis stem cankers was also shown to differ if the petioles were cut near the stem or if petiole stubs of varying length were left on the plants (Verhoeff, 1967). However, there is a need for clarification of this phenomenon, as conflicting results were later reported in different experimental conditions (Verhoeff, 1968). This question is of practical interest for protection as the growers have the possibility of controlling the size of the petiole stubs that are left on the plants during pruning.

The objective of our work was to investigate whether the pruning technique influences stem canker development caused by $B$. cinerea. A multivariate study was conducted in an experimental greenhouse and the results were validated in the pres- ence of natural inoculum in commercial greenhouses differing in environmental and agronomic conditions.

\section{MATERIALS AND METHODS}

\subsection{Experimental sites}

Studies were conducted in heated tomato greenhouses at four sites located in Southern France. One site was an INRA experimental greenhouse where cultural practices were kept close to those employed by local growers except that the plants received no fungicide treatments. Validation experiments were conducted at three sites in commercial greenhouses which were selected in order to obtain a wide range of agro-environmental conditions (Tab. I) and were known for regular occurrence of Botrytis epidemics. At the L'Islesur-la-Sorgue site, the experiment was conducted in adjacent greenhouses to assess within-site variability. In all commercial greenhouses, the plants were trellised and fertigated by the growers according to common local practices. Heating was achieved through fan jet systems located at a height of 1 metre above the soil and the climate was regulated manually by the growers. The crops differed mainly in terms of the substrate, the cultivar and planting density, and climatic conditions (Tab. I). Differences were also recorded in the fungicide treatments applied by the growers against grey mould. In L'Isle-sur-la-Sorgue, plants were treated with Bordeaux mixture before removal of the first leaves and with procymidone before the fourth leaf pruning operation. At the Pertuis site, the spraying regime was more intensive, with an application of Bordeaux mixture before removal of the first leaves, followed by four treatments during the leaf pruning period (dichlofluanide, procymidone, diethofencarb + carbendazim and Bordeaux mixture) and finally, three treatments after the last leaf pruning (procymidone twice, and diethofencarb + carbendazim). No fungicide was applied at the Perpignan site.

\subsection{Pruning treatments and experimental designs}

In the experimental greenhouse, four treatments were compared. For three of the treatments, four leaves were removed per plant. They were either broken off by hand close to the stem (treatment A) or the petioles were cut with pruning shears $5 \mathrm{~cm}$ (treatment B) or $10 \mathrm{~cm}$ (treatment C) from the stem. The 
Table II. Pruning techniques and experimental design to investigate whether the pruning technique influences stem canker development caused by $B$. cinerea. Leaves were broken off by hand close to the stem (treatment A) or cut with pruning shears $5 \mathrm{~cm}$ (treatment B) or $10 \mathrm{~cm}$ (treatment $\mathrm{C}$ ) from the stem. In treatment $\mathrm{D}$, leaves were left intact. The pruning treatments were arranged in randomised complete block designs.

\begin{tabular}{|c|c|c|c|c|c|}
\hline \multirow{2}{*}{ Location } & \multicolumn{3}{|c|}{ Plant pruning } & \multicolumn{2}{|c|}{ Block designs } \\
\hline & Techniques & $\begin{array}{c}\text { Number of } \\
\text { dates }\end{array}$ & $\begin{array}{l}\text { Number of leaves } \\
\text { removed per plant }\end{array}$ & $\begin{array}{l}\text { Number of } \\
\text { replications }\end{array}$ & $\begin{array}{c}\text { Number of } \\
\text { plants per plot }\end{array}$ \\
\hline INRA Montfavet & $\mathrm{ABCD}$ & 1 & 4 & 4 & 8 \\
\hline L'Isle/Sorgue & $\mathrm{ABC}$ & 4 & 20 & 2 & 16 \\
\hline Perpignan & $\mathrm{ABCD}$ & 3 & 9 & 3 & 20 \\
\hline Pertuis & $\mathrm{AB}$ & 7 & 50 & 3 & 32 \\
\hline
\end{tabular}

fourth treatment consisted of plants for which the four leaves were tagged but left intact (treatment D). Due to constraints linked to commercial production, it was not possible to set up an identical design in the four commercial greenhouses, either in terms of pruning schedule or in terms of the deleafing method as described in Table II. In all greenhouses, the pruning treatments were arranged in randomised complete block designs (Tab. II). In the experimental greenhouse, the whole design was duplicated, to allow for two modes of wound inoculation as described below.

\subsection{Inoculation}

The experiments in commercial greenhouses relied on natural inoculum of $B$. cinerea. In the experimental greenhouse, we applied artificial inoculum to ensure the development of disease. Half of the plants were artificially inoculated immediately after the leaf pruning, and half were left to natural inoculum. For treatments A, B and C, a conidial suspension of strain $\mathrm{BC} 1$ of $B$. cinerea was applied to the pruning wounds with a micropipette (ca. 5000 spores per wound). On leaves left intact in treatment $\mathrm{D}$, the conidial suspension was applied as a localised spray (ca. 1000 spores per leaf). The doses of inoculum were chosen on the basis of preliminary studies on the minimal concentrations of spore suspensions that allowed symptom expression in our experimental conditions. The inoculum was produced from cultures on Potato-Dextrose-Agar medium (Difco Laboratories, Detroit, Michigan) in Petri dishes $(90 \mathrm{~mm}$ diameter) incubated for 10 days with a photoperiod of 14 hours and a daily temperature alternation of $23{ }^{\circ} \mathrm{C}$ (during the day) and $18{ }^{\circ} \mathrm{C}$ (in the dark). A stock culture of this strain, originally isolated from a greenhouse-grown tomato, in Plougastel, France in 1989 , has been kept at $-20{ }^{\circ} \mathrm{C}$ in a mixture of glycerol and $0.06 \mathrm{M}$ phosphate buffer $(50 / 50, \mathrm{~V} / \mathrm{V})$. The conidial suspension was prepared by washing the surface of the cultures with sterile demineralised water and filtering through sterile muslin to remove mycelium fragments prior to adjustment to the desired concentrations.

\subsection{Disease assessment and data analysis}

The plants were examined repeatedly for Botrytis symptoms after the first leaf pruning (only once at the end of the growing season for the experiment in Perpignan). We recorded the incidence of infection on the pruning wounds (and where appropriate, on leaves left intact) as well as the resulting stem cankers. The areas under the disease progress curves (AUDPC) were computed as described by Aissat et al. (2008) to express the cumulative incidence of the deleafing method over an experiment or a growing season (all experiments except Perpignan trial). The treatments were compared by analysis of variance, using STATISTICA software (StatSoft, Inc., Tulsa, USA). Newman-Keuls tests and Fisher's protected least significant difference were used for multiple comparisons of means. Data representing percentages were arcsine-root transformed prior to analysis as suggested by Zar (1996).

\section{RESULTS AND DISCUSSION}

\subsection{Effect of pruning techniques on wound infection and stem canker development under experimental conditions}

The first symptoms of $B$. cinerea infections were observed within 7 days after pruning on artificially inoculated plants. On the plants pruned with methods that left $5 \mathrm{~cm}$ or $10 \mathrm{~cm}$ petiole stubs (treatments B and C, respectively), the incidence of wound infection reached nearly $50 \%$ within the 2 nd week after inoculation and then continued to increase at a slow and quasilinear rate $(0.66 \%$ per day on average for both treatments; $P<$ 0.05 and $\mathrm{R}^{2}>0.90$ for linear regressions) to reach ca. $70 \%$ by the end of the experiment (Fig. 1A). In contrast, the incidence of wound infection remained very low $(<6.5 \%)$ throughout the duration of the experiment on plants pruned without leaving petiole stubs (treatment A). Infections also occurred on leaves that were tagged and left intact (treatment D). Their incidence increased steadily throughout the duration of the experiment $\left(1.3 \%\right.$ per day on average; $P<0.05$ and $\mathrm{R}^{2}>0.90$ for linear regression).

On the plants that were not artificially inoculated, the pruning wounds and leaves were exposed to natural infestation with airborne inoculum of $B$. cinerea and infections were also observed. However, these infections appeared later and less frequently than on inoculated plants, with a rapid increase in infection incidence for one pruning treatment (treatment $\mathrm{B}$ ) 189 days after sowing (Fig. 1A).

The pruning technique had a significant $(P<0.05)$ impact on disease development regardless of if artificial or natural 
$1 \mathrm{~A}$ Infected pruning wounds or leaves $(\%)$

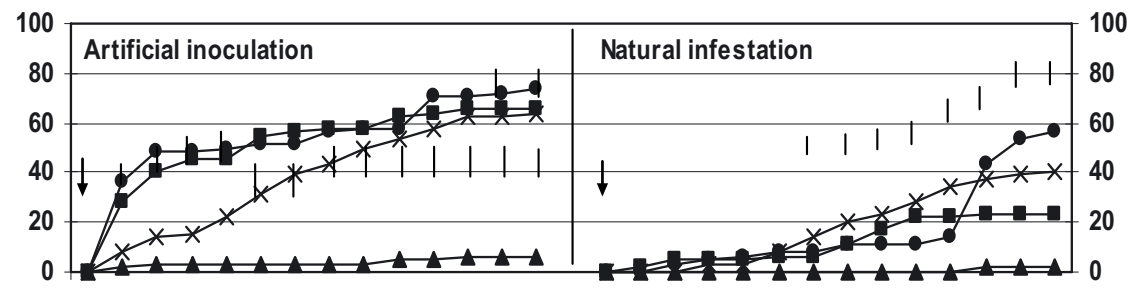

1B Pruning wounds or leaves developing stem cankers (\%)

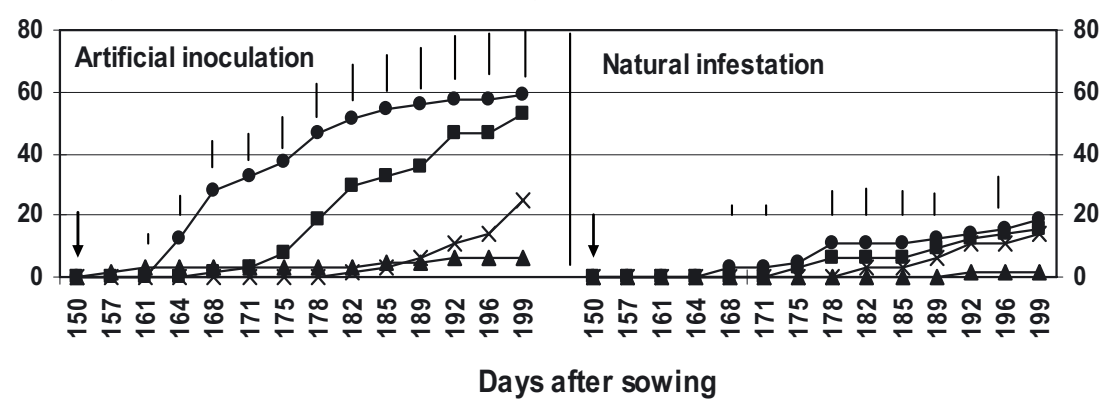

Figure 1. Influence of the leaf pruning technique on the infection of wounds and leaves $(1 \mathrm{~A})$ by $B$. cinerea and on the development of stem cankers (1B) in an experimental greenhouse in conditions of artificial inoculation or natural infestation. Leaves were broken off by hand close to the stem (treatment $\mathrm{A}, \boldsymbol{\Lambda}$ ) or the petioles were cut with pruning shears $5 \mathrm{~cm}$ (treatment $\mathrm{B}, \bullet$ ) or $10 \mathrm{~cm}$ (treatment $\mathrm{C}$, $\mathbf{\square}$ ) from the stem. In treatment D, leaves were left intact $(\mathbf{X})$. The arrows indicate the date of leaf removal. For each observation date, vertical bars represent Fisher's protected least significant differences $(P \leqslant 0.05)$. In all situations, disease development was significantly reduced in treatment $\mathrm{A}$.

infection was involved (Tab. III). This effect was detected for most observation dates, as indicated by the bars representing Fisher's protected least significant differences in Figure 1A. For all experiments, the percentage of infected pruning wounds at the end of the growing season was significantly reduced when leaves were cut close to the stem (treatment A). The incidence of wound infection was higher when the petiole stubs left on the plants during pruning were $5 \mathrm{~cm}$ (treatment B) than $10 \mathrm{~cm}$ (treatment $C$ ) long, with statistically significant differences $(P<0.05)$ in conditions of natural infestation (Tab. III).

From its point of entry on the wound, the fungus established itself first on the tissue exposed by pruning and then progressively spread on the adjacent tissues. When pruning consisted of complete removal of the leaf (treatment A), wound infection took place directly on the stem tissue. For all other treatments, the initial infection took place on the petiole (treatments B and C) or on the leaf blade (treatment D) and was followed by the colonisation of the petiole stub (or whole leaf) before the pathogen could reach the stem. On inoculated plants of treatments A, B and C, stem cankers were first observed 7, 11 and 25 days, respectively, after wound infection (Figs. 1A and 1B). Delays between initial infection and stem canker development were also observed on naturally infested plants. Cankers developed 11-13 days later on plants pruned $10 \mathrm{~cm}$ from the stem than on those pruned $5 \mathrm{~cm}$ from the stem.

The effect of the pruning methods on the kinetics of stem canker development was more obvious on artificially inoculated than on naturally infested plants (Fig. 1B). In both situ- ations, disease developed the slowest on plants where leaves were removed close to the stem (treatment A) and the fastest on plants where pruning left $5 \mathrm{~cm}$ petiole stubs (treatment B). This translated into significant $(P<0.05)$ differences in the AUDPC between these two pruning methods (Tab. III).

These results show that the method used for leaf pruning strongly affects the risk of wound infection and in turn, the incidence of resulting stem cankers. Complete removal of the leaf consistently reduced the risk of wound infection five to ten fold compared with pruning methods that leave petiole stubs attached to the plants. This suggests in turn that stem tissues may be less susceptible than petiole stubs to direct infection and colonisation by $B$. cinerea. The mechanisms involved in this phenomenon remain to be fully elucidated, but could be related to differences in the wound-induced reactions of the different tissues following the removal of the leaves (Bostock and Stermer, 1989). Among the many reactions triggered by wounds in a tomato plant (with possible effects against plant pathogens), several are systemic while others have tissue-specific expressions (Köck et al., 2004; Ryan, 2000; Stankovic et al., 2000). Jasmonic acid and systemin, components of a wound-signalling pathway in tomato, were found to be involved in resistance against $B$. cinerea (Diaz et al., 2002).

Our results are convergent with observations by Verhoeff (1968) in two experimental tunnels. He showed that the number of stem cankers per plant was lower when leaves were cut off close to the stem than when 3- or $5 \mathrm{~cm}$ petiole stubs were left on the plants. These findings were in contrast with another 
Table III. Influence of leaf pruning technique on the infection of pruning wounds by $B$. cinerea and the resulting stem cankers in tomato greenhouses. Disease incidence was monitored after the introduction of inoculum (experimental greenhouse) and under conditions of natural inoculum (experimental and commercial greenhouses). Depending on the experiments, leaves were broken close to the stem $(0 \mathrm{~cm})$, cut 5 and $10 \mathrm{~cm}$ from the stem, or left intact.

\begin{tabular}{|c|c|c|c|c|c|c|c|c|c|}
\hline \multirow{2}{*}{ Experiment } & \multirow[b]{2}{*}{$\begin{array}{l}\text { Pruning } \\
\text { technique }\end{array}$} & \multicolumn{4}{|c|}{ Disease incidence $(\%)^{\mathrm{u}}$} & \multicolumn{4}{|c|}{ AUDPC $^{v}$} \\
\hline & & \multicolumn{2}{|c|}{$\begin{array}{l}\text { Wound or leaf } \\
\text { infection }\end{array}$} & \multicolumn{2}{|c|}{$\begin{array}{l}\text { Stem canker } \\
\text { development }\end{array}$} & \multicolumn{2}{|c|}{$\begin{array}{l}\text { Wound or leaf } \\
\text { infection }\end{array}$} & \multicolumn{2}{|c|}{$\begin{array}{l}\text { Stem canker } \\
\text { development }\end{array}$} \\
\hline \multicolumn{10}{|c|}{ Experimental greenhouse (Montfavet) } \\
\hline \multirow[t]{4}{*}{ Artificial inoculation } & A: $0 \mathrm{~cm}$ & 6.2 & $b^{w}$ & 6.2 & $\mathrm{c}$ & 171.1 & $\mathrm{c}$ & 171.1 & $\mathrm{c}$ \\
\hline & B: $5 \mathrm{~cm}$ & 73.4 & a & 59.4 & $\mathrm{a}$ & 2528.1 & a & 1614.9 & a \\
\hline & $\mathrm{C}: 10 \mathrm{~cm}$ & 65.6 & $\mathrm{a}$ & 53.1 & $\mathrm{a}$ & 2407.8 & a & 861.7 & $\mathrm{~b}$ \\
\hline & D: none & 64.1 & a & 25.0 & $\mathrm{~b}$ & 1719.6 & $\mathrm{~b}$ & 163.3 & $\mathrm{c}$ \\
\hline \multirow[t]{4}{*}{ Natural infestation } & A: $0 \mathrm{~cm}$ & 1.6 & $\mathrm{~d}$ & 1.6 & $\mathrm{~b}$ & 13.3 & $\mathrm{~b}$ & 13.3 & $\mathrm{~b}$ \\
\hline & B: $5 \mathrm{~cm}$ & 56.2 & $\mathrm{a}$ & 18.8 & $\mathrm{a}$ & 691.4 & a & 328.9 & $\mathrm{a}$ \\
\hline & $\mathrm{C}: 10 \mathrm{~cm}$ & 23.4 & $\mathrm{c}$ & 15.6 & $\mathrm{a}$ & 552.3 & $\mathrm{a}$ & 225.8 & $a b$ \\
\hline & D: none & 40.6 & $\mathrm{~b}$ & 14.1 & $\mathrm{a}$ & 799.2 & a & 141.4 & $a b$ \\
\hline \multicolumn{10}{|c|}{ Commercial greenhouses } \\
\hline \multirow[t]{3}{*}{ L'Isle/Sorgue 1} & A: $0 \mathrm{~cm}$ & 12.3 & $\mathrm{c}$ & 12.3 & $\mathrm{~b}$ & 798.4 & $\mathrm{c}$ & $798.4^{\mathrm{x}}$ & \\
\hline & B: $5 \mathrm{~cm}$ & 85.8 & a & 27.9 & $\mathrm{a}$ & 6620.6 & a & 640.8 & \\
\hline & $\mathrm{C}: 10 \mathrm{~cm}$ & 78.9 & $\mathrm{~b}$ & 23.4 & a & 4911.1 & $\mathrm{~b}$ & 591.2 & \\
\hline \multirow[t]{3}{*}{ L'Isle/Sorgue 2} & A: $0 \mathrm{~cm}$ & 5.8 & $\mathrm{c}$ & 5.8 & $\mathrm{c}$ & 252.3 & $\mathrm{c}$ & $252.3^{x}$ & \\
\hline & B: $5 \mathrm{~cm}$ & 86.1 & $\mathrm{a}$ & 29.9 & $\mathrm{a}$ & 6511.3 & a & 437.9 & \\
\hline & $\mathrm{C}: 10 \mathrm{~cm}$ & 74.4 & $\mathrm{~b}$ & 21.2 & $\mathrm{~b}$ & 4360.8 & $\mathrm{~b}$ & 459.6 & \\
\hline \multirow[t]{4}{*}{ Perpignan } & A: $0 \mathrm{~cm}$ & 3.7 & & 3.7 & $\mathrm{~b}$ & $\mathrm{nc}^{\mathrm{z}}$ & & $\mathrm{nc}^{z}$ & \\
\hline & $\mathrm{B}: 5 \mathrm{~cm}$ & $n d^{y}$ & & 23.2 & $\mathrm{a}$ & $\mathrm{nd}^{\mathrm{y}}$ & & $\mathrm{nc}$ & \\
\hline & $\mathrm{C}: 10 \mathrm{~cm}$ & nd & & 12.4 & $\mathrm{~b}$ & nd & & $\mathrm{nc}$ & \\
\hline & D: none & nd & & 8.2 & $\mathrm{~b}$ & nd & & $\mathrm{nc}$ & \\
\hline \multirow[t]{2}{*}{ Pertuis } & A: $0 \mathrm{~cm}$ & 1.3 & & 1.3 & $\mathrm{a}$ & 47.2 & & 47.2 & $\mathrm{~b}$ \\
\hline & B: $5 \mathrm{~cm}$ & $\mathrm{nd}^{\mathrm{y}}$ & & 2.0 & $\mathrm{a}$ & nd & & 86.2 & $\mathrm{a}$ \\
\hline
\end{tabular}

u At the end of the experiment or growing season.

${ }^{v}$ Areas under the disease progress curves.

${ }^{\mathrm{w}}$ For a given experiment, values followed by the same letter are not significantly different according to the Newman-Keuls test $(P \leqslant 0.05)$.

x No significant differences $(P \geqslant 0.10)$.

${ }^{y}$ nd: no data.

${ }^{\mathrm{Z}}$ nc: not computed because disease incidence was monitored only once at the end of the cropping season.

study (Verhoeff, 1967) in which the same author showed that stem infection was lower when long petiole stubs $(\geqslant 3 \mathrm{~cm})$ were left on the plants than when short petiole stubs were left or when leaves were completely removed. In this latter study, the reduction in the incidence of stem cankers in the presence of long petiole stubs was attributed to the abscission and the fall of infected petiole stubs before they could become fully colonised by the pathogen and could give it access to stem tissue. Under similar experimental conditions (artificial inoculation on young potted plants) we also occasionally observed the abscission of infected petiole stubs within 4-5 days (unpublished data).

\subsection{Validation under commercial conditions}

In all trials in commercial greenhouses, a significant effect of the deleafing method was observed both on the incidence of wound infection and on that of stem cankers at the end of the growing season (Tab. III). In L'Isle-sur-la-Sorgue, where the epidemics were monitored over several months, the kinetics of wound infection were similar in two adjacent greenhouses and the differences between pruning treatments remained significant $(P<0.05)$ from the second date of observation until the end of the trial (Fig. 2A). In both greenhouses, the incidence of wound infection under natural infestation reached levels comparable with those observed on artificially inoculated plants in the experimental greenhouse in Montfavet. In contrast, the development of stem cankers was slow and strongly delayed in the commercial greenhouses. The highest incidence of stem cankers (observed on the plants with $5 \mathrm{~cm}$ petiole stubs) did not increase beyond $30 \%$ in the commercial greenhouses (Fig. 2B), while it reached nearly $60 \%$ on artificially inoculated plants in the experimental greenhouse (Fig. 1B and Tab. III).

In all commercial greenhouses, complete removal of the leaves consistently reduced the incidence of wound infection 


\section{A Infected pruning wounds or leaves (\%)}

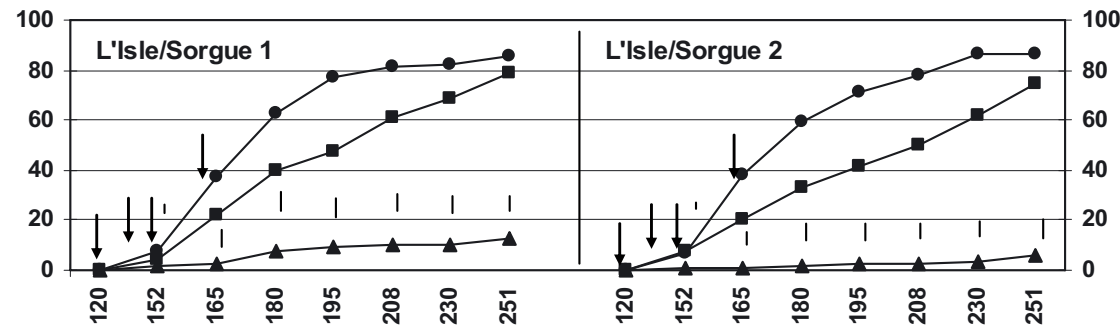

2B Pruning wounds or leaves developing stem cankers (\%)

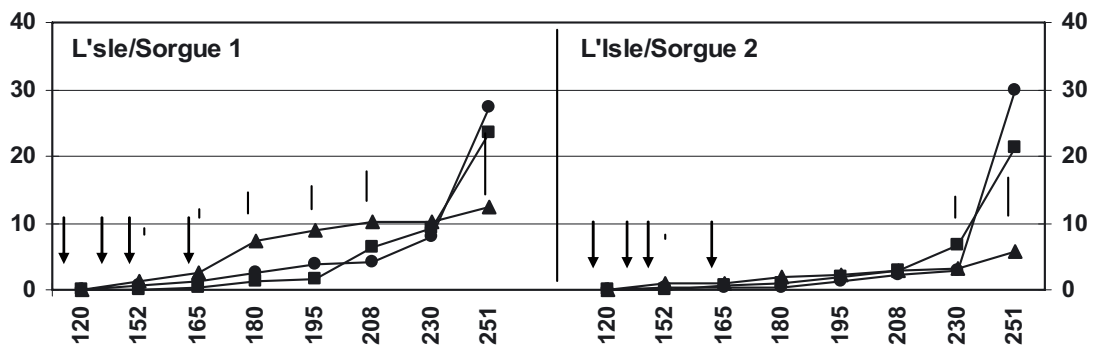

Figure 2. Influence of the deleafing method of tomato plants on the kinetics of infection of pruning wounds by B. cinerea (2A) and development of stem cankers (2B) in two adjacent greenhouses in L'Isle-sur-la-Sorgue. Leaves were broken off by hand close to the stem (treatment A, $\mathbf{\Delta}$ ) or the petioles were cut with pruning shears $5 \mathrm{~cm}$ (treatment $\mathrm{B}, \bullet$ ) or $10 \mathrm{~cm}$ (treatment $\mathrm{C}, \mathbf{\square}$ ) from the stem. The arrows indicate the dates of leaf removal. For each date, vertical bars represent Fisher's protected least significant differences $(P \leqslant 0.05)$. In the two adjacent greenhouses, disease development was significantly reduced in treatment A.

and the development of stem cankers at the end of the growing season in comparison with other pruning methods (Tab. III). A statistically significant effect $(P<0.05)$ was found between plants pruned close to the stem or $5 \mathrm{~cm}$ from the stem in all but one trial (experiment in Pertuis). In the Pertuis trial, where disease incidence remained overall extremely low, the differences between the two pruning treatments were statistically significant when compared over the whole growing season (AUDPC data, Tab. III). In comparison, such significant differences between AUDPC data were not observed for the experiment conducted in L'Isle-sur-la-Sorgue due to the late development of stem cankers (Tab. III).

Whether tested under experimental conditions or in a diversity of commercial situations, all the results of the present study clearly indicate that a significant reduction in the risk of wound infection can be expected when leaves are fully removed in comparison with methods that leave petiole stubs on the plants. Our results also indicate that refraining from pruning the leaves would not necessarily prevent the development of Botrytis stem cankers in heated greenhouses. This is consistent with observations in unheated tunnels in Israel (where leaf pruning is uncommon) that stem cankers may result from the colonisation of the petiole by the pathogen following direct infection and colonisation of the leaf (Shtienberg et al., 1998). In the heated greenhouses, where excess humidity is usually kept under control, direct leaf infection by $B$. cinerea is rare but occasionally reported (Nicot and Baille, 1996). In the present experiments conducted in heated commercial and experimental greenhouses, infection occurred later on leaves left intact (no-pruning treatment) than on petiole stubs, but the incidence of resulting stem cankers was not insignificant.

None of the leaf removal techniques examined in the present study could completely prevent the infection of leafpruning wounds by $B$. cinerea. However, careful removal of the leaves without leaving petiole stubs on the stems proved useful for significantly decreasing the risk of infection. The adoption of such a meticulous practice would probably require specific training of the greenhouse workers and potentially increase the labour costs. A specific study would need to be carried out on this question, as it is possible that the potentially increased working time could be balanced by a reduction in the time currently dedicated to highly labour-intensive curative measures such as applying fungicidal pastes on detected stem cankers. Moreover, its implementation should result in reduced need for pesticide application and thus in a decrease in the risk of development of resistant strains of $B$. cinerea to fungicides. As inoculum produced on stem cankers has been shown to have a strong epidemiological impact (Decognet et al., 2009), another possible benefit associated with improved pruning would be a general decrease in the inoculum pressure in the greenhouse.

This cultural method could be adopted in complement to other environmentally-friendly control methods such as preventive treatments of the wounded surfaces with biological control agents (Elad and Stewart, 2004; Nicot et al., 2002; Utkhede and Mathur, 2006) or the systematic removal of inoculum sources inside the greenhouses. This sanitation method based on removal of dead plants and plant debris 
before sporulation of $B$. cinerea could further reduce the epidemiological impact of endogenous inoculum produced on infected dead tissues (Aerts et al., 2007a; Decognet et al., 2009). Modelling the infection risk for stem wounds by spores of $B$. cinerea could also be useful for tomato growers to decide on the choice of treatments as shown by Aerts et al. (2007b).

The potential of such methods could also be evaluated for the protection of pruning wounds against infection by ascospores of Sclerotinia sclerotiorum in greenhouse tomato production and against $B$. cinerea, Didymella bryoniae (causal agent of gummy stem blight) and Penicillium oxalicum (causal agent of Penicillium stem rot) in greenhouse cucumber production.

\section{CONCLUSION}

Leaf pruning is a common cultural practice in heated tomato greenhouses but this practice enhances the risk of stem infection by exposing the wounds to spores of $B$. cinerea. In this study, we compared deleafing techniques in experimental and commercial greenhouses, in a variety of agronomic conditions and in various situations of inoculum pressure. Our results clearly showed that a careful removal of the leaves without leaving petiole stubs on the stems can significantly decrease the incidence of stem cankers even under high disease pressure. In consequence, we suggest improving working practices in tomato greenhouses by removing leaves close to the stem. However, as this cultural method could not completely prevent the infection of leaf-pruning wounds by $B$. cinerea, it should be integrated in a complete strategy of grey mould management including a variety of nonchemical control methods in the greenhouse, such as sanitation measures, and climatic and biological control. This environmentally-friendly cultural practice appears compatible for combination with these methods in the objective of sustainable crop protection from diseases and pests in greenhouse tomatoes.

\section{REFERENCES}

Aerts R., Denayer A., Seels B., Heyens K. (2007a) Sustainable control of Botrytis by sanitation and cultural measures, in: 14th International Botrytis Symposium, Cape town, South Africa, 2007/10/21-26, p. 72 .

Aerts R., Denayer A., Seels B., Heyens K. (2007b) Modelling infection of Botrytis cinerea in tomato as a tool for better control, in: 14th International Botrytis Symposium, Cape town, South Africa, 2007/10/21-26, p. 85.

Aissat K., Nicot P.C., Guechi A., Bardin M., Chibane M. (2008) Grey mould development in greenhouse tomatoes under drip and furrow irrigation, Agron. Sustain. Dev. 28, 403-409.

Besri M., Diatta F. (1992) Effect of fungicide application techniques on the control of Botrytis cinerea and development of fungal resistance, in: Verhoeff K., Malathrakis N.E., Williamson B. (Eds.), Recent advances in Botrytis research, Pudoc Scientific Publishers, Wageningen, Netherlands, pp. 248-251.

Bostock R.M., Stermer B.A. (1989) Perspectives on wound healing in resistance to pathogens, Annu. Rev. Phytopathol. 27, 343-371.
Candido V., D’Addabbo T., Basile M., Castronuovo D., Miccolis V. (2008) Greenhouse soil solarization: effect on weeds, nematodes and yield of tomato and melon, Agron. Sustain. Dev. 28, 221-230.

Decognet V., Bardin M., Trottin-Caudal Y., Nicot P.C. (2009) Rapid change in the genetic diversity of Botrytis cinerea populations after the introduction of strains in a tomato glasshouse, Phytopathology 99, 185-193.

Diaz J., ten Have A., van Kan J.A.L. (2002) The role of ethylene and wound signaling in resistance of tomato to Botrytis cinerea, Plant Physiol. 129, 1341-1351.

Dik A.J., Wubben J.P. (2004) Epidemiology of Botrytis cinerea diseases in greenhouses, in: Elad Y., Williamson B., Tudzynski P., Delen N. (Eds.), Botrytis: biology, pathology and control, Kluwer Academic Publishers, Dordrecht, The Netherlands, pp. 319-333.

Elad Y., Shtienberg D. (1995) Botrytis cinerea in greenhouse vegetables: chemical, cultural, physiological and biological controls and their integration, Integr. Pest Manage. Rev. 1, 15-29.

Elad Y., Stewart A. (2004) Microbial control of Botrytis spp., in: Elad Y., Williamson B., Tudzynski P., Delen N. (Eds.), Botrytis: biology, pathology and control, Kluwer Academic Publishers, Dordrecht, The Netherlands, pp. 223-241.

Jarvis W.R. (1980) Epidemiology, in: Coley-Smith J.R., Verhoeff K., Jarvis W.R. (Eds.), The Biology of Botrytis, Academic Press, London, UK, Vol. 8, pp. 219-250.

Jarvis W.R. (1992) Managing diseases in greenhouse crops, American Phytopathological Society, St Paul, MN.

Köck M., Gross N., Stenzel I., Hause G. (2004) Phloem-specific expression of the wound-inducible ribonuclease LE from tomato (Lycopersicon esculentum cv. Lukullus), Planta 219, 233-242.

Leroux P. (2004) Chemical control of Botrytis and its resistance to chemical fungicides, in: Elad Y., Williamson B., Tudzynski P., Delen N. (Eds.), Botrytis: Biology, Pathology and Control, Kluwer Academic Publishers, Dordrecht, The Netherlands, pp. 195-222.

Nicot P.C., Baille A. (1996) Integrated control of Botrytis cinerea on greenhouse tomatoes, in: Morris C.E., Nicot P.C., Nguyen-The C. (Eds.), Aerial Plant Surface Microbiology, Plenum Press, New York, pp. 169-189.

Nicot P.C., Decognet V., Fruit L., Bardin M., Trottin Y. (2002) Combined effect of microclimate and dose of application on the efficacy of biocontrol agents for the protection of pruning wounds on tomatoes against Botrytis cinerea, IOBC/WPRS Bull. 25, 73-76.

O’Neill T.M., Hilton G. J., Pye D. (1998) Effect of fruit truss removal on occurrence of Botrytis stem lesions in protected tomatoes, in: 7th International Congress of Plant Pathology, Edinburgh, Scotland, 1998/08/9-16, pp. 6-31.

O’Neill T.M., Shtienberg D., Elad Y. (1997) Effect of some host and microclimate factors on infection of tomato stems by Botrytis cinerea, Plant Dis. 81, 36-40.

Ryan C.A. (2000) The systemin signaling pathway: differential activation of plant defensive genes, Biochim. Biophys. Acta 1477, 112-121.

Schellhorn N.A., Nyoike T.W., Liburd O.E. (2009) IPM programs in vegetable crops in Australia and USA: Current status and emerging trends, in: Peshin R., Dhawan A.K. (Eds.), Integrated Pest Management: Innovation-Development Process, Springer, pp. 575598.

Shipp L., Elliott D., Gillespie D., Brodeur J. (2007) From chemical to biological control in Canadian greenhouse crops, in: Vincent C., Goettel M.S., Lazarovits G. (Eds.), Biological Control: A Global Perspective, CAB International, pp. 118-127. 
Shtienberg D., Elad Y., Niv A., Nitzani Y., Kirshner B. (1998) Significance of leaf infection by Botrytis cinerea in stem rotting of tomatoes grown in non-heated greenhouses, Eur. J. Plant Pathol. 104, 753-763.

Stankovic B., Vian A., Henry-Vian C., Davies E. (2000) Molecular cloning and characterization of a tomato c-DNA encoding a systematically wound-inducible bZIP DNA-binding protein, Planta 212, 60-66.

ten Have A., van Berloo R., Lindhout P., van Kan J.A.L. (2007) Partial stem and leaf resistance against the fungal pathogen Botrytis cinerea in wild relatives of tomato, Eur. J. Plant Pathol. 117, 153166.

Utkhede R.S., Mathur S. (2006) Preventive and curative biological treatments for control of Botrytis cinerea stem canker of greenhouse tomatoes, Biocontrol 51, 363-373. van Lenteren J.C. (2000) A greenhouse without pesticides: fact or fantasy? Crop Prot. 19, 375-384.

Verhoeff K. (1967) Studies on Botrytis cinerea in tomatoes. Influence of methods of deleafing on the occurence of stem lesions, Neth. J. Plant Pathol. 73, 117-120.

Verhoeff K. (1968) Studies on Botrytis cinerea in tomatoes. Effect of soil nitrogen level and of methods of deleafing upon the occurence of Botrytis cinerea under commercial conditions, Neth. J. Plant Pathol. 74, 184-192.

Williamson B., Tudzynski B., Tudzynski P., van Kan J.A.L. (2007) Botrytis cinerea: the cause of grey mould disease, Mol. Plant Pathol. 8, 561-580.

Zar J.H. (1996) Biostatistical Analysis, Prentice Hall, New York. 